ASIAN JOURNAL OF MANAGEMENT STUDIES

Journal homepage: https://www.sab.ac.lk/ajms/

Faculty of Management Studies Sabaragamuwa University of Sri Lanka

\title{
Factors influencing Youth Unemployment in Sri Lanka
}

\author{
ARP Weerasiri and GRSRC Samaraweera \\ Department of Economics and Statistics, Faculty of Social Sciences and Languages, \\ Sabaragamuwa University of Sri Lanka, Belihuloya, Sri Lanka
}

\begin{abstract}
The potential stock of human capital among youth is a leading factor for accelerating the economic growth of a country via maximising full capacity utilisation. The main purpose of this study is to identify the factors influencing youth unemployment in Sri Lanka using a subsample of 3,562 youths derived from the Sri Lanka Labour Force Survey, 2018. Findings stemmed from binary logistic regression analysis revealed that skill mismatch, including language and digital literacy and geographical mismatch, including province, influences youth unemployment in Sri Lanka. Moreover, this study showed that the probability of being unemployed is high among young females, youths who are educated up to post-secondary level, vocationally trained youths, and youths with high levels of language and digital literacy. The findings highlight the importance of improving the country's human capital in terms of education and vocational training and allow policymakers to rethink the possible reforms in the education and vocational training systems to improve knowledge, skills, attitudes, and the mindsets of the youth targeting job orientations.
\end{abstract}

Keywords: Geographical Mismatch, Job Expectation of Youth, Youth Unemployment, Skill Mismatch
(C) Faculty of

Management Studies

Sabaragamuwa

University of Sri Lanka

ARTICLE INFO

Article history:

Received: 30 November 2020

Accepted: 11 January 2021

Published: 09 February 2021

E-mail Address: rashipraba773@gmail.com sumadi@ssl.sab.ac.lk 


\section{INTRODUCTION}

The United Nations has defined the term "youth" as a person between the ages of 15-24 years; however, the definition of youth varies from country to country based on customs, traditions, behaviours, and location (Msigwa \& Kipesha, 2013). In line with the United Nations' definition, the age group of 15-24 has been defined as youth in this study. This age group comprises humans who are more energetic, courageous, and have new technological ideas essential for the growth and expansion of a country's economic development (Msigwa \& Kipesha, 2013). In most developing countries, the youth between the ages of 15-24 years are still gaining knowledge to improve their human capital stock, which is essential for the labour market. Despite this importance, the youth has faced a significant challenge of unemployment in both developing and developed countries (Dagume \& Gyekey, 2016). According to the Department of Census and Statistics (2017), unemployed is defined as a person who does not have a job for more than four weeks and who is willing, available and is taking all the necessary actions to find a job, and ready to accept a job offer within two weeks. Unemployment is considered as a multidimensional concept combined with economic, political, and social dimensions. Also, it depends on the fields of economy, social setting, culture, and education system. Therefore, it is a difficult concept to measure and define (Msigwa \& Kipesha, 2013). The problem of unemployment is more severe among youths than adults in both developed and developing countries (Dagume \& Gyekey, 2016).

The lack of experience, skills mismatch, and leaving school at young ages are considered the causes of youth unemployment in most nations, and youth unemployment positively affected social, political, and economic instability (Msigwa \& Kipesha, 2013). As a result, it will increase criminal activities, civil conflicts, depression, dependence on family, drug addiction, and suicide in the economy (Natrass, 2002). Furthermore, youth unemployment will lead to higher poverty, income inequality, low economic development, and economic growth (Sam, 2016).

According to Dagume and Gyekey (2016), youth unemployment is a global challenge faced by both developed and developing countries. The ILO (2010) has identified that $90 \%$ of youth are centred in developing countries and leading to higher underemployment and poverty in those countries. 
Moreover, the youth unemployment rate in the world has been recorded at around 13\% from 2012 to 2017 (ILO, 2015, 2017). This rate remained stable in South Asia at $10.9 \%$ in 2017.

In line with the world context, Sri Lanka is also facing the problem of youth unemployment. There was unprecedented growth in youth unemployment between 2013 to 2016 as $19.2 \%, 20.3 \%, 20.8 \%$, and $21.6 \%$, respectively (Department of Census and Statistics, 2018). However, it has a sudden drop in the year 2017 at $18.5 \%$. By the year 2018, it increased again up to $21.4 \%$ (Department of Census and Statistics, 2018). In 2018, according to the Department of Census and Statistics (2018), 372,593 persons were unemployed in Sri Lanka, and 197,448 of them were youth (15-24). The youth contributes the highest proportion of overall unemployment in Sri Lanka, representing the youth unemployment rate as $21.4 \%$. According to Hettige et al. (2004), unemployment in Sri Lanka experiences an unequal distribution by gender and region.

Moreover, in 2018, the youth unemployment rate for females was $30 \%$ and $16.8 \%$ for males. One of the main reasons for the higher female youth unemployment rate is female workers' preference to work closer to where they live (Nanayakkara, 2004). The Central Province recorded the highest youth unemployment rate of $31.3 \%$ in 2018 , and youth unemployment is higher among the youth having G.C.E. (A/L) and above qualifications (Department of Census and Statistics, 2018). According to the above statistics, youth unemployment is a major problem in Sri Lanka. Youth unemployment has been stagnating in Sri Lanka for years due to a lack of proper remedies such as a social security network or active labour market policies to absorb the unemployed youth into the labour market. Moreover, most of the job opportunities in industrial and service sectors are placed in the Western Province at present, and most unemployed educated youth do not have adequate resources to invest in self-employment opportunities (Nanayakkara, 2004), leading to social multidimensional youth unemployment issues in the society (Department of Census and Statistics, 2017). Based on the above backdrop, this study attempts to identify the factors influencing youth unemployment in Sri Lanka. 
This study's findings will be significant to employers, government institutions, and labour market policymakers. Further, there is a significant lack of literature and well-organised empirical studies examining factors associated with youth unemployment in Sri Lanka. Therefore, this study contributes to literature highlighting skill mismatch, including language literacy and digital literacy and geographical mismatch, including provinces as the factors associated with youth unemployment in Sri Lanka.

\section{LITERATURE REVIEW}

Both theoretical and empirical literatures were reviewed under this section. Theoretical literature discusses four main theories, including efficiency wage theory, human capital theory, mismatched hypothesis, and job searching. When firms pay higher wages than the equilibrium wage in order to increase the efficiency of the workers, it will cause the creation of unemployment due to the reduction of new recruitments. According to the efficiency wage theory, when wages are kept higher than the market wage, it causes to reduce employee turnover and increase the efficiency of the employees (Shapiro \& Stiglitz, 1984). Akerlof (1982) identified that efficiency wage is also higher paid wages to reduce the adverse selection of job seekers and provide rewards for the higher productivity of workers. In the efficiency wage framework, the workers are unable to secure their employment since they have no capacity to increase wage bills and high productivity.

Sometimes unemployment also occurs due to market clearance. The workers take time to find and move into new jobs, and the employers take time and resources to identify and recruit suitable new workers to fill their vacancies. That time will lead to the creation of voluntary unemployment. This type of unemployment is called 'frictional search unemployment' and occurs for a short time (Baah-Boateng, 2013). At that time, the search theory is used to examine frictional unemployment (Baah-Boateng, 2013).

Another type of unemployment is structural unemployment that may occur due to the mismatch between demand for labour and the skills and location of the job seekers. It is related to the unemployment that may arise due to the technological advancements that make the skills of some job seekers obsolete (Baah-Boateng, 2013). 
In addition to skills mismatch, there are several types of mismatches that affect youth unemployment, such as attitude mismatch, geographical mismatch, and demographic mismatch.

The human capital theory is one of the most popular among all the above theories that explain how education and training affect the labour market (Dagume \& Gyekye, 2016). According to this theory, individuals can increase their skills, productivity and income by investing more human capital in education and training. Therefore, education and training levels can be a cause of unemployment.

According to Hettige et al. (2004), unemployment in Sri Lanka was not only affected by the skills mismatch but also the slow growth and restrictive policies in the labour market that influenced the limiting of sufficient employment creation.

The empirical literature is basically classified under demographic, skill, economic and geographical factors. Among the demographic factors, age, gender, marital status, and household size are the key concerns. Age is the most prevalent factor in youth unemployment. Baah-Boateng (2013) examined that age (15-24) has a positive marginal effect on unemployment. However, Shita and Dereje (2016) identified that when age increases by one year, then the odds ratio of youth unemployment decreases at a $1 \%$ significance level. Qayyum (2007) examined youth unemployment by age, and he identified that age has a negative relationship with youth unemployment. On the other hand, Tegegne (2019) and Dagume and Gyekye (2016) found age is an insignificant factor in youth unemployment. Based on the above evidence, the study employed age to contribute to youth unemployment in Sri Lanka.

Most of the scholars studied gender as a factor causing youth unemployment. As per Batu (2016), Msigwa and Kipesha (2013), and Qayyum (2007), the female youth unemployment rate is higher than the male youth unemployment rate. Baah-Boateng (2013) has identified that being female had a positive and significant impact on unemployment in 1991/92. Further, Rathnayaka et al. (2010) stated that the female unemployment rate is higher in Sri Lanka. 
However, Dagume and Gyekye (2016) and Tegegne (2019) explained that gender does not significantly affect youth unemployment. According to Hettige et al. (2004), Sri Lanka has also experienced unequal distribution of unemployment between men and women. This was mainly affected by discriminatory practices in relation to their market access. Most of the females in Sri Lanka select arts subjects in school than men, and this also leads to the high rate of female unemployment in Sri Lanka (Hettige et al. 2004).

Another important factor is marital status. Chikako (2018) stated that married youth is positively related to the youth unemployment with reference to the never married youth. However, Batu (2016) identified that the low level of unemployment rate is recorded by the never married, divorced, separated, widowed, and those living together when considering married as a base. Msigwa and Kipesha (2013) identified that the single, married and widowed unemployment rate is high with reference to the separated youths. Qayyum (2007) identified a lower unemployment rate among married youth than nonmarried youth. However, Dagume and Gyekye (2016) and Shita and Dereje (2016) identified that marital status has an insignificant effect on youth unemployment.

Youth unemployment is high in small-sized households compared to large-sized households. However, the youth unemployment of medium-sized households did not statistically significant (Chikako, 2018).

Demographic factors such as age, gender, marital status, and household size were identified as factors influencing youth unemployment in previous studies lead to the following hypothesis.

$\mathrm{H}_{1}=$ There is a relationship between the youth unemployment and demographic factors

Education, digital literacy skills, training, and language literacy levels are also key concerns related to skills leading to youth unemployment. Most scholars have used education as a factor influencing youth unemployment. However, Baah-Boateng (2013) identified that having basic education in 1991/92 and 2005/06 and secondary education in 2005/06 have significant marginal effects on unemployment. Also, Batu (2016) identified that the youths with certificate, diploma, or above qualifications have a better chance of getting jobs. Shita and Dereje (2016) identified statistically significant 
differences among different educational levels. Most commonly, they identified that the persons with higher education become unemployed. However, Dagume and Gyekye (2016) have identified that education affecting youth unemployment is insignificant. According to Hettige et al. (2004), Sri Lankan educated youth are not willing to accept "any job" and stay outside if that the job does not satisfy their job preference in the market.

Vocational training is also a significant factor in youth unemployment. Ali and Jabeen (2016) also stated that the lack of training was one of the main reasons for the unemployment in the formal sector. Dagume and Gyekye (2016) and Terzo and Giaconia (2018) identified a negative relationship between vocational training and youth unemployment. Further, they explained that a low vocational training level would lead to a high youth unemployment level.

Language literacy level has a significant effect on youth unemployment in urban Ethiopia. The odds of unemployment for youth who are unable to read and write was about $49.7 \%$ higher than the odds of unemployment for youth who are able to read and write (Chikako, 2018). According to Gunatilaka et al. (2010), the poor English language skill was identified as a key barrier to employment among youth in Sri Lanka.

Shita and Dereje (2016) found that the skills match and youth unemployment are negatively related. On the other hand, Msigwa and Kipesha (2013) concluded that the youth without skills are less likely to be unemployed than skilled youth.

This study used digital literacy and language variables as proxy variables to indicate the available skills of youth in Sri Lanka. According to the previous studies, skills such as education, language literacy level, vocational training and digital literacy were identified as critical factors associated with youth unemployment. Thus, the following hypothesis is built.

$\mathrm{H}_{2}=$ There is a relationship between youth unemployment and skill factors

Among the economic factors, household income is the key concern. Shita and Dereje (2016) conducted research by employing family prosperity, and they identified that medium-income families are less unemployed than those from poor income families. According to the literature, the economic factors such as household income was identified as a determinant of youth 
unemployment, and the respective hypothesis is given below.

$\mathrm{H}_{3}=$ There is a relationship between youth unemployment and economic factors

Among the geographical factors, the residential sector and province are the key concerns. The residential sector is also a significant factor leading to youth unemployment. Msigwa and Kipesha (2013) concluded that the youth living in rural areas could be employed easily due to the informal nature of employment opportunities as agriculture sector than urban sector. Because, in urban areas, youth have to improve their education, skills, and experiences to be employed in formal job opportunities. Also, Rathnayaka et al. (2010) identified that being in the rural sector decreases unemployment in Sri Lanka, drawing concern on most being in the estate sector.

Terzo and Giaconia (2018) recognised that the Central region and Northern region are negatively associated with youth unemployment with reference to the Southern region in Italy. In Sri Lanka, the overall unemployment rate is lower in the Western Province than in the other provinces (Rathnayaka et al., 2010). Hettige et al. (2004) also reported that Sri Lanka has sharp regional disparities regarding unemployment.

As such, geographical factors such as residential sector and province were reported as significant determinants of youth unemployment by the literature, thus forming the fourth hypothesis of the study.

$\mathrm{H}_{4}=$ There is a relationship between youth unemployment and geographical factors

\section{METHODOLOGY}

To identify the factors associated with youth unemployment, most research studies, such as those by Misgwa and Kipesha (2013) and Qayyum (2007), have employed the quantitative approach as their research approach. This study also used the quantitative approach since this study decided to employ secondary data to analyse youth unemployment factors.

Some researchers, such as Gebisa and Etana (2019) and Dagume and Gyekye (2016), have employed primary data collection methods to collect data using structured questionnaires. However, most researchers, like Sever 
and Igdeli (2018), have used secondary data from several surveys. This study also used the secondary data collection method using micro-level data of Sri Lanka Labour Force Survey (SLLFS) in 2018. According to the SLLFS, in $2018,11,947$ youth aged between 15 to 24 were included in Sri Lanka's labour force. Out of the 11,917 observations, 3,562 had been selected as the sample of this study after dropping the inactive youth. Out of 3,562 chosen observations, the study identified 776 unemployed and 2,786 employed youth.

Youth unemployment is measured as a binary variable having two values, 0 and 1 . Moreover, the study identified 11 factors contributing to youth unemployment and those related to the schedule questions in the SLLFS, 2018. According to the study, the researcher divided the identified factors into four categories: demographic, skill, economic, and geographical factors. Demographic factors comprised of age, gender, marital status and household size.

Age and household size were measured as a continuous variable, and gender and marital status were defined as dummy variables. Concerning skill factors education, digital literacy, vocational training, and language literacy level were measured. Education was measured in two groups: pre-secondary or below (with no schooling and up to G.C.E. O/L) and post-secondary or above education (with G.C.E. A/L and above). Language literacy was measured using four categories: ability to read and write only in one language, ability to read and write in two languages, ability to read and write in three languages, and unable to read and write in any language. The digital literacy variable was prepared using question number C03 and C05 in the SLLFS 2018 schedule. Vocational training was measured by using questions numbered 62 to 64 in the SLLFS 2018 schedule. Under economic factors, household income was considered. Household income is calculated by adding all family members' incomes (primary job income and secondary job income). In geographical factors, the residential sector and province are concerned.

The residential sector was measured as people who are living in the urban, rural and estate sector. Province was measured concerning nine provinces in Sri Lanka.

Data were analysed using binary logistic regression model using STATA/MP13 (64-bit) statistical software package. 


\section{RESULTS AND DISCUSSION}

The study revealed that $16.8 \%$ of male and $30 \%$ of female youth are unemployed in Sri Lanka. The unemployment rate of female youth is higher than that of the male youth in Sri Lanka, showing the gender-based disparities in the country's labour market. Both demand and supply factors associated with employment facilitates the males than the females. More job opportunities are available for males since males are ready to accept any employment due to fewer social barriers.

According to the descriptive statistics shown in Table 1, one-fifth of the youth are unemployed in Sri Lanka. The majority of the sample comprised of unmarried males. One-third of the sample had a post-secondary or above level of education. The majority of the sample had literacy in only one language and had digital literacy. Only 16 per cent of the youth have obtained vocational training, and most youth are from the rural sector. The highest proportion of youth in the sample was from the Western Province while the Southern and Central Provinces come second and third.

According to Table 2, age is significantly and negatively related to the probability of being unemployed when considering demographic factors. The youth are more likely to be employed when their age is increased concerning the base category. Sri Lankan youth are more likely to engage in educational activities. However, when their age increases, they try to get a job suitable to their education level and qualifications. Also, educated and qualified youth are less likely to be unemployed when their age increases. They are more likely to improve their social status as their age increases. Therefore, when age increases, the probability of youth being unemployed will decrease concerning the base category. 
Table 1: Descriptive Statistics

\begin{tabular}{|c|c|c|}
\hline \multirow[t]{2}{*}{ Model } & \multicolumn{2}{|c|}{$\begin{array}{l}\text { Total Youth } \\
\end{array}$} \\
\hline & Mean /Proportion & SD \\
\hline Dependent Variable - Youth Unemployment & 0.2179 & 0.4128 \\
\hline Gender - Female $\left(D_{1}\right)$ & 0.3436 & 0.4749 \\
\hline Male (Ref) & 0.6563 & 0.4749 \\
\hline Age $\left(X_{1}\right)$ & 21.2257 & 2.1621 \\
\hline Marital Status - Married $\left(\mathrm{D}_{2}\right)$ & 0.1519 & 0.3589 \\
\hline Unmarried (Ref) & 0.8481 & 0.3589 \\
\hline Household Size $\left(X_{2}\right)$ & 4.5797 & 1.5546 \\
\hline $\begin{array}{l}\text { Education - post secondary and above } \\
\left(\mathrm{D}_{3}\right)\end{array}$ & 0.3478 & 0.4764 \\
\hline Pre secondary and below(Ref) & 0.6522 & 0.4764 \\
\hline Literacy - One Language Literacy $\left(\mathrm{D}_{4}\right)$ & 0.6864 & 0.4640 \\
\hline Two Language Literacy $\left(\mathrm{D}_{5}\right)$ & 0.2482 & 0.4320 \\
\hline Three Language Literacy $\left(D_{6}\right)$ & 0.0517 & 0.2214 \\
\hline No Language Literacy (Ref) & 0.0138 & 0.1165 \\
\hline $\begin{array}{l}\text { Digital Literacy - Having Digital Literacy } \\
\left(\mathrm{D}_{7}\right)\end{array}$ & 0.2419 & 0.4284 \\
\hline Not Having Digital Literacy (Ref) & 0.7580 & 0.4284 \\
\hline Training - Having Training $\left(\mathrm{D}_{8}\right)$ & 0.1656 & 0.3718 \\
\hline Not having Training (Ref) & 0.8343 & 0.3718 \\
\hline Residential Sector (D) - Urban Sector $\left(\mathrm{D}_{9}\right)$ & 0.1654 & 0.3716 \\
\hline Rural Sector $\left(D_{10}\right)$ & 0.7791 & 0.4149 \\
\hline Estate Sector (Ref) & 0.0556 & 0.2292 \\
\hline Province - Western Province (Ref) & 0.2153 & 0.4111 \\
\hline Central Province $\left(\mathrm{D}_{11}\right)$ & 0.1209 & 0.3262 \\
\hline Southern Province $\left(D_{12}\right)$ & 0.1232 & 0.3288 \\
\hline Northern Province $\left(D_{13}\right)$ & 0.1319 & 0.3385 \\
\hline Eastern Province $\left(\mathrm{D}_{14}\right)$ & 0.0974 & 0.2966 \\
\hline North-Western Province $\left(\mathrm{D}_{15}\right)$ & 0.1092 & 0.3119 \\
\hline North-Central Province $\left(\mathrm{D}_{16}\right)$ & 0.0609 & 0.2392 \\
\hline Uva Province $\left(D_{17}\right)$ & 0.0469 & 0.2114 \\
\hline Sabaragamuwa Province $\left(\mathrm{D}_{18}\right)$ & 0.0940 & 0.2919 \\
\hline Household Income $\left(\mathrm{X}_{3}\right)\left(000^{\prime}\right)$ & 60.2393 & 75.5422 \\
\hline
\end{tabular}

Source: Researcher developed by using SLLFS, 2018, N = 3562

On the other hand, according to the Ben Porath model, the persons have reduced human capital investment when they reach the retirement age. That means human capital investment increases at an increasing rate when their age increases. Therefore, people are more likely to be employed when their age increases. According to the above points, increasing age by year decreases youth's probability of being unemployed by $2.35 \%$ concerning the base category. Negative relationship of age with youth unemployment is supported by a similar finding of Rathnayaka et al. (2010) regarding general unemployment in Sri Lanka. 
Table 2: Logistic Regression Model for Youth Unemployment in Sri Lanka

\begin{tabular}{lrrrr}
\hline Variable & $\begin{array}{l}\text { Logistic } \\
\text { Coefficient }\end{array}$ & S.E & P Value & \multicolumn{1}{c}{$\begin{array}{l}\text { Marginal } \\
\text { Effect }\end{array}$} \\
\hline Gender - Being a female $\left(\mathrm{D}_{1}\right)$ & 0.5319 & 0.0947 & 0.000 & 0.0726 \\
Age $\left(\mathrm{X}_{1}\right)$ & -0.1725 & 0.0232 & 0.000 & -0.0235 \\
Marital Status - Married $\left(\mathrm{D}_{2}\right)$ & -0.6157 & 0.1547 & 0.000 & -0.0840 \\
Education - Post-Secondary and above & 0.9272 & 0.1149 & 0.000 & 0.1266 \\
$\left(\mathrm{D}_{3}\right)$ & & & & \\
Literacy - One Language Literacy $\left(\mathrm{D}_{4}\right)$ & 1.1367 & 0.5794 & 0.050 & 0.1552 \\
Two Language Literacy $\left(\mathrm{D}_{5}\right)$ & 1.3959 & 0.5882 & 0.018 & 0.1906 \\
Three Language Literacy $\left(\mathrm{D}_{6}\right)$ & 1.2499 & 0.6110 & 0.041 & 0.1706 \\
Digital Literacy - Having digital literacy & 0.2648 & 0.1228 & 0.031 & 0.0361 \\
(D) & & & & \\
Training - Having vocational training $\left(\mathrm{D}_{8}\right)$ & 0.7719 & 0.1163 & 0.000 & 0.1054 \\
Residential Sector - Urban Sector $\left(\mathrm{D}_{9}\right)$ & -0.3206 & 0.2455 & 0.191 & -0.0438 \\
Rural Sector $\left(\mathrm{D}_{10}\right)$ & -0.4713 & 0.2079 & 0.023 & -0.0643 \\
Province - Central Province $\left(\mathrm{D}_{11}\right)$ & 0.9617 & 0.1816 & 0.000 & 0.1313 \\
Southern Province $\left(\mathrm{D}_{12}\right)$ & 0.8173 & 0.1730 & 0.000 & 0.1116 \\
Northern Province $\left(\mathrm{D}_{13}\right)$ & 0.2826 & 0.1798 & 0.116 & 0.0386 \\
Eastern Province $\left(\mathrm{D}_{14}\right)$ & 0.5894 & 0.1938 & 0.002 & 0.0805 \\
North-Western Province $\left(\mathrm{D}_{15}\right)$ & 0.1836 & 0.1875 & 0.328 & 0.0251 \\
North-Central Province $\left(\mathrm{D}_{16}\right)$ & 0.6661 & 0.2191 & 0.002 & 0.0909 \\
Uva Province $\left(\mathrm{D}_{17}\right)$ & 0.7707 & 0.2414 & 0.001 & 0.1052 \\
Sabaragamuwa Province $\left(\mathrm{D}_{18}\right)$ & 0.4659 & 0.1975 & 0.018 & 0.0636 \\
Household Size $\left(\mathrm{X}_{2}\right)$ & 0.1807 & 0.0333 & 0.000 & 0.0247 \\
Household income $\left(\mathrm{X}_{3}\right)$ & -0.0242 & 0.0028 & 0.000 & -0.0033 \\
Constant & 0.5419 & 0.7659 & 0.479 & - \\
\hline Note: Base Category & & & &
\end{tabular}

Note: Base Category: A person who is unable to read and write in any language, not having digital literacy, not having vocational training, pre-secondary or below educated, living in the estate sector, living in Western Province, unmarried, male.

Source: Researcher developed by using SLLFS, 2018

Among demographic factors, household size of youth is considered in this research, and it is significantly and positively related to the probability of being unemployed (Table 2). Persons with increasing household size are less likely to be employed concerning the base category. When household size increases, unemployment will also increase as most people in the family have jobs with adequate family income. Then youth will not have an urgent need to get a job due to less financial problems. These youths will try to get further qualifications such as higher education and qualifications in computer technology and English to improve their earnings by using these qualifications. On the other hand, when household size increases, youth have less responsibility in the household. This finding is also supported by the study of Chikako (2018) as small-sized households represented higher youth unemployment. 
When moving to the next demographic factor, gender is a significant factor for youth unemployment. Table 2 shows that being a female made a youth in Sri Lanka, about 7.26\% more likely to be unemployed. Concerning gender, being a female is positively related to the unemployment of youth. This indicates that female youth have lesser chances to be employed than the male youth. Male youth are likely to increase their earnings by accepting any jobs.

Also, female youth are discriminated against in the labour market, and this could be affected by gender-specific harassments at work, increasing travel distance, lack of proper transport facilities, lack of awareness programmes on cultural and religious barriers, lack of proper daycare facilities for young mothers and the lack of employment opportunities for females due to pre-market and market discriminations in Sri Lanka. Based on the above points if a person is a female, then the probability of being unemployed increases concerning the base category. This finding is also supported by Rathnayake et al. (2010), Batu (2016), Msigwa and Kipesha (2013) and Qayyum (2007). In Sri Lanka, unemployed male and female youth will be expected to work in different occupations. Most of the females are seeking white-collar jobs, including general office clerks, ICT related jobs and teaching than that of males according to Table 3 .

Table 3: Analysis of Nature of Expected Occupation based on Gender

\begin{tabular}{|c|c|c|}
\hline \multirow[t]{2}{*}{ Nature of Expected Occupation } & \multicolumn{2}{|c|}{ Gender } \\
\hline & $\begin{array}{c}\text { Female } \\
\%\end{array}$ & $\begin{array}{c}\text { Male } \\
\%\end{array}$ \\
\hline Commercial and Sales Agents, Shopping Sales Partners & 1.79 & 4.66 \\
\hline $\begin{array}{l}\text { Information and Technology Activation Technician, Motor } \\
\text { Mechanics and Repairers and Production Technician }\end{array}$ & 5.71 & 11.47 \\
\hline General Office Clerk & 27.5 & 13.98 \\
\hline $\begin{array}{l}\text { Bank Recipients, Payers and Associate Clerks and } \\
\text { Accountancy and Book Keepers }\end{array}$ & 6.43 & 2.51 \\
\hline $\begin{array}{l}\text { Cleaners of Hotels and Other Institutes and Office Helpers } \\
\text { and Security Regulators }\end{array}$ & 3.57 & 12.19 \\
\hline $\begin{array}{l}\text { Nurses, Secondary Teachers, Teachers in pre-schools and } \\
\text { Other Government Assistant Professionals }\end{array}$ & 15 & 1.43 \\
\hline $\begin{array}{l}\text { Tailors, Designers, Fur Merchants and Hat Makers, Drivers of } \\
\text { Car, Taxi and Van and Employees Engaged in Basic } \\
\text { Occupations }\end{array}$ & 6.43 & 5.73 \\
\hline Other & 33.57 & 48.03 \\
\hline Total & 100 & 100 \\
\hline
\end{tabular}

Note: There are 279 males and 280 females who responded to the question of 56 in the SLLFS, 2018.

Source: Researcher developed 
Among demographic factors, marital status is a significant factor for the presence of youth unemployment. Table 2 shows that being married made a youth in Sri Lanka, about $8.4 \%$ less likely to be unemployed. In the society, married youth have more responsibilities and financial problems than unmarried youth. Therefore, married youth are likely to do any job to maintain their marriage life smoothly. However, unmarried youth are likely to spend their time further on education to improve their qualifications. Previous studies of Rathnayaka et al. (2010) and Qayyum (2007) identified that the unemployed rate of unmarried people is higher than the married due to marital and dependency responsibilities entitled to their respective life cycle stages. According to the above findings, demographic factors including age, gender, marital status, and household size have significant relationships with the youth unemployment of Sri Lanka, proving the first hypothesis of the study.

When considering skill factors, education is the most significant factor for youth unemployment. In this study, education is categorised into presecondary and below and post-secondary education and above. According to this study's results, post-secondary and above education is significantly related to youth unemployment concerning base category (Table 2). This means regarding their being pre-secondary and below educated, the youth with postsecondary and above education are less likely to be employed. It means that when the education level increases, employment probability will decrease as it is the most practical situation in Sri Lanka. When considering the Sri Lankan situation, the most educated person will always try to get jobs with high social status and job security. Moreover, people who have pre-secondary and below education will always try to get any job to improve their earnings. They are less likely to be unemployed than more educated people because they know they do not have jobs with high social status for their educational qualifications. That means post-secondary and above-educated youth have higher expectations about their job than pre-secondary educated and below persons. Rathnayaka et al. (2010)'s previous study further supported a positive relationship between unemployment and education in Sri Lanka. The postsecondary and above educated group is waiting for jobs as clerks, ICT assistants, secondary teachers, and accountancy and bookkeepers. Less market opportunities are created in the job market for such occupations, thus increasing the probability of being unemployed (Table 4). 
Among skill factors, digital literacy is a significant factor in the presence of youth unemployment. According to Table 2, the results show that being a youth with digital literacy made a youth about $3.61 \%$ more likely to be unemployed than a youth without digital literacy. That means the youth without digital literacy are less likely to be unemployed than youth with digital literacy. Because youth without digital literacy knows they cannot get a whitecollar job for their available qualifications. However, the youth with digital literacy will always try to get a job by comparing their qualifications. Yet, a youth with digital literacy has less chance to be employed as the jobs' expectation is based on the qualifications. However, youth without digital literacy are likely to engage in any job with fewer skills. According to the above points, being a youth with digital literacy increases the probability of being unemployed concerning the base category. Skilled youth with digital literacy are waiting for better jobs that could utilise their skills at work leading to unemployment arose due to the skill mismatch. Studies of Shita and Dereje (2016) also identified skills match and youth unemployment are negatively associated.

Table 4: Analysis of nature of Expected occupation based on Education

\begin{tabular}{|c|c|c|}
\hline \multirow{2}{*}{ Nature of Expected Occupation } & \multicolumn{2}{|c|}{ Education } \\
\hline & $\begin{array}{l}\text { Pre-secondary } \\
\text { or below } \%\end{array}$ & $\begin{array}{l}\text { Post-secondary } \\
\text { or above } \%\end{array}$ \\
\hline $\begin{array}{l}\text { Nurses and Other Government Assistant } \\
\text { Professionals }\end{array}$ & 2.44 & 4.79 \\
\hline $\begin{array}{l}\text { Commercial and Sales Agents and Shopping } \\
\text { Sales Partners }\end{array}$ & 5.69 & 1.60 \\
\hline $\begin{array}{l}\text { Information and Technology Activation } \\
\text { Technician, Motor Mechanics and Repairers } \\
\text { and Production Technician }\end{array}$ & 8.13 & 9.90 \\
\hline General Office Clerk & 8.94 & 30.03 \\
\hline $\begin{array}{l}\text { Accountant Associate Technicians, Bank } \\
\text { Recipients, Payers and Associate Clerks and } \\
\text { Accountancy and Book Keepers }\end{array}$ & - & 9.90 \\
\hline $\begin{array}{l}\text { Tailors, Designers, Fur Merchants and Hat } \\
\text { Makers, Drivers of Car, Taxi and Van and } \\
\text { Employees Engaged in Basic Occupations }\end{array}$ & 13.41 & 0.96 \\
\hline $\begin{array}{l}\text { Cleaners of Hotels and Other Institutes and } \\
\text { Office Helpers }\end{array}$ & 11.38 & 3.19 \\
\hline Secondary Teachers and Teachers & - & 7.67 \\
\hline Other & 50 & 31.95 \\
\hline Total & 100 & 100 \\
\hline
\end{tabular}

Note: There are 246 youths with pre-secondary or below education and 313 youths with postsecondary or above education who responded to question 56 in the SLLFS, 2018.

Source: Researcher developed 
Vocational training is another skill factor positively and significantly related to youth unemployment (Table 2). The results show that being a youth with vocational training made a youth person about $10.54 \%$ more likely to be unemployed than a youth person without vocational training in Sri Lanka. This means youth without vocational training are less likely to be unemployed as they always try to engage in any job while believing that work experience is the most valuable factor in their future employment. Youth with any vocational training will be less likely to be employed because they have higher expectations for finding a job suitable for their qualifications and training. Due to the above reasons, if being a youth with vocational training, the probability of being unemployed increases concerning the base category. Clerical and ICT based occupations are sought after by the vocationally trained people, leading to the same issue of inadequate availability of such jobs in the real market (Table 5). However, Dagume and Gyekye (2016) identified a negative relationship between vocational training and youth unemployment.

Table 5: Analysis of Nature of Occupation based on Training

\begin{tabular}{|c|c|c|}
\hline \multirow[t]{2}{*}{ Nature of Occupation } & \multicolumn{2}{|c|}{ Training } \\
\hline & $\begin{array}{l}\text { Having } \\
\text { Training } \\
\%\end{array}$ & $\begin{array}{l}\text { Not Having } \\
\text { Training } \\
\%\end{array}$ \\
\hline $\begin{array}{l}\text { Nurses, Secondary Teachers and Accountancy and Book } \\
\text { Keepers }\end{array}$ & 11.62 & 7.20 \\
\hline $\begin{array}{l}\text { Information and Technology Activation Technician, } \\
\text { Production Technician and Motor Mechanics and } \\
\text { Repairers }\end{array}$ & 14.65 & 5.26 \\
\hline General Office Clerk & 16.16 & 23.27 \\
\hline $\begin{array}{l}\text { Cleaners of Hotels and Other Institutes and Office } \\
\text { Helpers }\end{array}$ & 3.54 & 8.59 \\
\hline $\begin{array}{l}\text { Commercial and Sales Agents and Shopping Sales } \\
\text { Partners }\end{array}$ & 1.01 & 4.43 \\
\hline $\begin{array}{l}\text { Tailors, Designers, Fur Merchants and Hat Makers, } \\
\text { Drivers of Car, Taxi and Van and Employees Engaged } \\
\text { in Basic Occupations }\end{array}$ & 3.03 & 8.31 \\
\hline Other & 50 & 42.94 \\
\hline Total & 100 & 100 \\
\hline
\end{tabular}

Note: There are 198 youths with training and 361 youths without training who responded to question 56 in the SLLFS, 2018.

Source: Researcher developed

Among skill factors, language literacy is the most significant factor for youth unemployment. In this study, language literacy is categorised by four categories: one language literacy, two language literacy, three language literacy and no language literacy. One language literacy, two language literacy and three language literacy, is positively and significantly related to youth 
unemployment. According to Table 2, the results show that being a youth with one, two, and three language literacy made a youth more likely to be unemployed than a youth with no language literacy. Concerning youth who cannot read and write any language, youth who can read and write one, two and three languages are less likely to be employed because they have a high expectation to be employed. Also, these youth believes that adequate literacy leads to be employed than no language literacy youth. Since most employers in Sri Lanka will focus on language literacy on their employees, the youth who can read and write multiple languages have more chances to be employed. These youths will always try to compare more chances due to their language literacy. Youth with language literacy are less likely to be employed with low wages and benefits due to their higher expectations.

This skills mismatch will cause high youth unemployment. Thus, if being a youth who can read and write one, two and three languages, the probability of being unemployed will increase concerning the base category. People without language literacy believe they cannot find job opportunities like other groups, and they will try to get any job immediately. Therefore, they are likely to engage in unskilled jobs available in the labour market. As these youths are likely to improve their earnings and have fewer employment opportunities, they will rarely give up any limited chance. Hence, the probability of being unemployed will increase concerning the base category for a youth person who can read and write one, two and three language literacy. According to the study of Rama (1999), skill mismatch is highly attributed to the higher unemployment rate in Sri Lanka.

Skill related factors, including education, digital and language literacy, vocational training has a significant positive relationship with youth unemployment showing the severity of skill mismatches in the labour market for Sri Lankan youth supporting the second hypothesis of the study.

The household income of youth is studied in this research while considering economic factors, and it is significantly and negatively related to the probability of being unemployed (Table 4). Youth with high household income are more likely to be employed concerning the base category. This is basically because higher income groups have many social networking which facilitate many employment opportunities for the high-income youth. Further, high-income families can engage in self-employment as they have enough capital to invest. According to the above points, increasing household income decreases youth unemployment by $0.33 \%$ concerning the base category. Shita 
and Dereje (2016) conducted a research and identified that medium-income families are less unemployed than those from poor income families.

Among geographical factors, the residential sector is the most significant factor for youth unemployment in Sri Lanka. Among these sectors, the rural sector is negatively and significantly related to youth unemployment. Results show that being in the rural sector made a youth about $6.43 \%$ less likely to be unemployed than a youth in the base category, including the estate sector (Table 4). Estate people are isolated and vulnerable in the society. Youth from the estate sector is facing many barriers in the entrance at the labour market including lack of availability of job opportunities, lack of required skills including language competencies and educational qualifications due to inadequate economic and social infrastructure facilities inherited by estate sector, lack of having outside employment opportunities and entering barriers to the labour market imposed by the estate management. They are victimised for both pre-market and market discriminations from their childhood due to the above factors. Majority of youth in estates do not desire to work at estate and need to migrate the other areas. However, their skills are not matched with the requirements of the outside employment opportunities of the country. Social status and social acceptance are positively affected by this pre-market discrimination, and therefore they have fewer chances to be employed.

For instance, estate sector youth have learned in the Tamil language. Still, most of the job opportunities available in the market require them to be literate in either Sinhala or English languages. This skill mismatch further keeps them away from the employment opportunities in the labour market. Studies of Msigwa and Kipesha (2013) have concluded that the youth living in rural areas can be employed easily due to the informal nature of employment opportunities such as in the agriculture sector. Further, Rathnayaka et al. (2010) identified that being in the rural sector decreases unemployment when compared to being in the estate sector, as found by the current study as a similar finding for youth unemployment.

When considering provinces, Western, Central, Southern, Eastern, North-Central, Uva and Sabaragamuwa Provinces are positively and significantly affected by the presence of youth unemployment (Table 4). The main reason for this is that the Western province youth enjoy more job opportunities since the industrial and services sector job opportunities are centred within the Western Province. Nearly forty per cent (38.5\%) of the GDP contribution was reported from the Western Province with the highest number 
of industries (CBSL, 2019). The development and industrial locations should be decentralised to create more opportunities for the other provinces. Also, higher education levels, qualifications, and skills of Western Province youth make them gain employment quickly in the labour market. When looking at the Central Province, the youth have limited job opportunities such as in the tea industry, vegetable production, and other minor estate sector activities. Therefore, they enjoy fewer employment opportunities and less education levels and qualifications. Also, people living in the Southern, Eastern, NorthCentral, Uva and Sabaragamuwa Provinces enjoy less job opportunities and education and skills than in the Western Province.

Therefore, people who live in the above provinces enjoy fewer job opportunities than in the Western Province. When considering the Western province, living in other provinces is positively associated with youth unemployment. The study has identified that this geographical mismatch positively affected youth unemployment in Sri Lanka based on the above points. Our findings reconfirm Rathnayake et al. (2010) findings, which has highlighted that Western Province has a lower rate of overall unemployment.

Based on the results of this study, all hypotheses of the study are accepted. Accordingly, the demographic factors (age, gender, marital status and household size), skill factors (education, digital literacy, language literacy and vocational training), economic factors (household income) and geographical factors (province and residential sector) influenced youth unemployment in Sri Lanka. Moreover, the value of Pseudo $\mathrm{R}^{2}$ is 0.1873 . It explains $18.73 \%$ of presence of youth unemployment described by all independent variables. The Likelihood Ratio test is used to identify whether the independent variables create significant impacts on youth unemployment. In this study, the p-value is less than the 5\% level. That explains that all independent variables of this model have significant impacts on youth unemployment. Therefore, the overall model is significant.

\section{CONCLUSION}

According to the study results, age and marital status decrease the probabilities of youth unemployment. Simultaneously, household size increases youth unemployment probability when comparing to the base category, leading to demographic disparities in the labour market. Being a female increases the probability of being unemployed, showing the gender- 
specific disparities in the labour market. Education (having post-secondary or above), language literacy (one language literacy, two language literacy, and three language literacy), digital literacy (having digital literacy), vocational training (having training) have significant positive relationships in Sri Lanka, proving an apparent mismatch among education, vocational training and the skills with the available market opportunities. This further concludes that skills mismatch is still a fundamental phenomenon of youth unemployment in Sri Lanka. On the other hand, household income has a negative relationship with youth unemployment in Sri Lanka. Geographical disparities including province (Central, Southern, Eastern, North-Central, Uva, and Sabaragamuwa) were positively related to youth unemployment concerning the base category with the Western Province, which is identified as the largest industrial establishment of the country. Further, the residential sector (rural sector) decreases the probability of being unemployed, leading to a geographical mismatch. Based on these findings, the following policy suggestions were developed by this study as vital contributions to the national policy authorities.

According to the results of the study, youth unemployment is higher for females than males. This could be affected by gender-specific harassments at work, increasing travel distance, lack of providing proper transport facilities, lack of awareness programmes on cultural and religious barriers, lack of proper daycare facilities for young mothers, and the lack of employment opportunities for females due to pre-market and market discriminations in Sri Lanka. A national-level intervention is needed to address these issues with a cohesive policy integration mechanism with the Ministry of Labour and the Ministry of Women and Child Affairs. Introducing flexi-working schedules would encourage females to be employed since it facilitates online working at home by reducing most of the above-mentioned issues.

Geographical mismatch positively affected the presence of youth unemployment. According to the study results, youth unemployment is higher in the estate sector than in the rural sector. This could be affected by the premarket discriminations of education facilities, lack of language literacy, and lack of outside employment opportunities in the estate sector. Also, youth unemployment is higher in all provinces except in the Western Province. The following suggestions are proposed by the study as solutions to address premarket discrimination. Self-employment opportunities such as animal farming and high valued crop growing techniques could be promoted among estate youth with the support of the Ministry of Plantation and Ministry of Labour. 
The estate authorities should intervene to relax specific estate management rules and regulations to ensure suitable jobs for educated and qualified youth in the estate sector. The industrial and service sector job opportunities aligned with national planning could be promoted for all provinces with the support of the respective provincial councils.

According to the study results, youth unemployment is higher among those who are post-secondary educated, vocationally trained, highly literate in one, two, or three languages, and well literate in digital practices. The following suggestions are proposed by the author as solutions. Most of the educated youth will expect to work as clerks. Therefore, the Ministry of Industry and Commerce should conduct programmes to raise awareness of job opportunities and the qualifications and education required for clerks and related white-collar employment opportunities. Banks and microfinance institutions should provide credit facilities and training in skills like electrical, carpentry etc., to unemployed youth through the Ministry of Labour to provide self-employment since their choice towards self-employment is relatively poor. The government should introduce new legislations for private companies to create more job opportunities to empower the trained but unemployed youth. The Ministry of Skills Development and Vocational Training should implement job fairs through Provincial Councils to empower youth possessing digital literacy. Awareness of new online employment opportunities could be provided for unemployed youth with digital literacy and high education and vocational training levels.

Most of the studies employed a standard set of drivers to identify the key drivers of youth unemployment in Sri Lanka in terms of its presence. However, this study employed some uncommon empirical determinants regarding skills mismatch used by fewer scholars to identify youth unemployment's critical drivers in Sri Lanka, including digital literacy and language literacy. Also, geographical, demographical, and economic mismatches of youth unemployment provide an update on respective literate fields in Sri Lanka.

However, this study contains some limitations that pave the way for new scholars to carry out further studies. This study examined unemployed youth between the ages of 15-24 years. This range of age has ignored the graduate unemployed young individuals. Most of the unemployed graduates are available in the economy. Hence, this study has ignored the causes of 
unemployed graduates. This could provide a direction by enhancing the age range to 15-29 for scholars in the future. Several factors affect youth unemployment in Sri Lanka, such as demand-side factors etc. This study has dropped the demand-side factors as it has used data from SLLFS 2018. The demand-side factors associated with the presence of youth unemployment is not available in the SLLFS 2018. However, this study could be further enhanced using primary data to reach more valuable findings for those demand-side factors.

\section{ACKNOWLEDGEMENT}

The Department of Census and Statistics in Sri Lanka should be acknowledged for providing micro-level data of the Sri Lanka Labour Force Survey in 2018 for this study.

\section{REFERENCES}

Akerlof, G. A. (1982). Labour contracts as partial gift exchange. The Quarterly Journal of Economics, 97(4), 543-569.

Ali, S., \& Jabeen, U. A. (2016). Determinants of Youth Unemployment - A Supply Side Analysis. European Journal of Business, Economics and Accountancy, 4(1), 97-105.

Baah-Boateng, W. (2013). Determinants of unemployment in Ghana. African Development Review, 25(4), 385-399.

Batu, M. M. (2016). Determinants of Youth Unemployment in Urban Areas of Ethiopia. International Journal of Scientific and Research Publications, $6(5)$.

Central Bank of Sri Lanka (CBSL). (2019). Annual Report.

Chikako, T. U. (2018) Multilevel Modelling of Determinants of Youth Unemployment in Urban Ethiopia: Bayesian Estimation Approach. International Journal on Data Science and Technology, 4(2), 67-78.

Dagume, M. A., \& Gyekye, A. (2016). Determinants of youth unemployment in South Africa: evidence from the Vhembe district of Limpopo province. Environmental Economics, 7(4), 59-67. 
Department of Census and Statistics. (2017). Sri Lanka Labour Force Survey (SLLFS) Annual Report - 2017.

Department of Census and Statistics. (2018). Sri Lanka Labour Force Survey (SLLFS) Annual Report - 2018.

Gebisa, D. A., \& Etana, N. G. (2019). Determinants of Graduate Youth Unemployment. International Journal of Islamic Business and Economics, 3(2), 90-103.

Gunatilaka, R., Mayer, M., Vodopivec, M. (2010). The Challenge of Youth Employment in Sri Lanka. Washington DC: The World Bank.

Hettige, S. T., Mayer, M., \& Salih, M. (2004). School-to-work transition of youth in Sri Lanka.http://www.ilo.org/wcmsp5/groups/public/@ed_emp/ @emp_elm/documents/publication/wcms_114297.pdf

International Labour Office (ILO). (2010). Global Employment Trends for Youth: Special issue on the impact of the global economic crisis on youth.

ILO. (2015). Global Employment Trends for Youth 2015: Scaling up investment in decent jobs for youth.

ILO. (2017). Global Employment Trends for Youth 2017: Paths to a better working future.

Msigwa, R., \& Kipesha, E. F. (2013). Determinants of youth unemployment in developing countries: Evidences from Tanzania. Journal of Economics and Sustainable Development, 4(14), 67-76.

Nanayakkara, A. G. W. (2004). Employment and Unemployment in Sri Lanka: Trends, Issues and Options. Department of Census and Statistic.

Natrass, N. (2002). Should Youth Employment be targeted as a part of a Comprehensive Welfare Policy in South Africa? Social Dynamics, 28(2), 207-236.

Qayyum, W. (2007). Causes of Youth Unemployment. The Pakistan Development Review, 46(4/2), 611-621. 
Rama, M. (1999). The Sri Lankan unemployment problem revisited. Washington DC: The World Bank Development Research Group.

Rathnayaka, R. M. L., Samaraweera, G. R. S. R. C., \& Jayasekara, Y. G. P. K., (2010). Determinants of Unemployment in Sri Lanka. In M. S. Shantha \& H. M. Bandara (Eds.) (Sinhala). Peace, Prosperity and Development: Challenges and Prospects of $21^{\text {st }}$ Century. Belihuloya: Sabaragamuwa University of Sri Lanka.

Sam, S. O. (2016). Modelling economic determinants of youth unemployment in Kenya. Journal of Emerging Trends in Economics and Management Sciences, 7(1), 31-38.

Sever, E., \& İgdeli, A. (2018). The determining factors of youth unemployment in developing countries: The Case of Turkey. International Journal of Social and Economic Sciences, 8(1), 75-83.

Shapiro, C., \& Stiglitz, J. E. (1984). Equilibrium unemployment as a worker discipline device. The American Economic Review, 74(3), 433-444.

Shita, A., \& Dereje, M. (2016). Determinants of Urban Youth Unemployment; Evidence from East Gojjam Zone, Ethiopia. International Journal of Economic Development, 11(2), 245-265.

Tegegne, T. K. (2019). Socioeconomic Determinants of Youth Unemployment in Ethiopia, the Case of Wolaita Sodo Town, Southern Ethiopia. Journal of Economics and Sustainable Development, 10(23), 46-53.

Terzo, G., \& Giaconia, C. (2018). The socio-demographic determinants of youth unemployment in Italy: Evidences from national labour survey. Paper presented at EconWorld2018, Seville, Spain. 